Bangl. J. Vet. Med. (2010). 8 (2) : 93-96

\title{
A CROSS-SECTIONAL STUDY FOR MYCOPLASMA GALLISEPTICUM ANTIBODIES IN NON-VACCINATED COMMERCIAL LAYER BIRDS IN KHULNA DISTRICT
}

\author{
M. A. Jalil ${ }^{* 1}$ and M. T. Islam ${ }^{2}$ \\ ${ }^{1}$ District Livestock Office, Khulna, ${ }^{2}$ Department of Medicine, Faculty of Veterinary Science, Bangladesh \\ Agricultural University, Mymensingh, Bangladesh \\ ${ }^{*}$ Corresponding author's e-mail : maj_dvm@yahoo.com
}

\begin{abstract}
A cross-sectional study was carried out on 96 commercial layer farms of six upazilas of Khulna district to know the seroprevalence of Mycoplasma gallisepticum (MG) infection during the period from August 2009 to July 2010. A total of 1268 sera samples were collected from randomly selected layer birds of different age groups and tested by serum plate agglutination (SPA) test by using commercial MG antigen (Nobilis ${ }^{\circledR}$ MG, Intervet International) to detect the presence of antibodies against MG. The overall prevalence of MG infection was recorded as $67.4 \%$. Age-wise analysis revealed that there was significant relationship ( $\mathrm{p}<0.001)$ between MG infection and age of birds. The highest prevalence of MG infection was $71.2 \%$ in $21-56$ weeks age group followed by $66.8 \%$ in $8-20$ weeks age group. There was significant $(\mathrm{p}<0.001)$ variation in the seroprevalence in terms of areas of study (upazilas). Significant $(\mathrm{p}<0.001)$ effect of seasons in the seroprevalence of $\mathrm{MG}$ infection in layer birds was observed in the present study. The prevalence of MG infection was the highest $(75.6 \%)$ in winter season followed by summer $(66.3 \%)$ and rainy $(60.8 \%)$ seasons. The seroprevalence of MG infection was higher in most of the large flocks and lower in small flocks with some exceptions. It is evident from the present study that above $50 \%$ layer birds are infected with MG organism. Therefore, it may be suggested that the layer farms should be routinely checked to monitor MG infection and the reactor birds should be culled since MG organism has the potential to transmit vertically.
\end{abstract}

Key words: Seroprevalence, Mycoplasma gallisepticum, serum plate agglutination (SPA), layer birds

\section{INTRODUCTION}

Mycoplasma gallisepticum (MG) is an important pathogen of poultry causing chronic respiratory disease (CRD) (Ley, 2003). MG infection occurs naturally in chickens and turkeys; however, MG has also been isolated from naturally occurring infections in many other domestic and wild birds (Jordan and Amin, 1980; Reece et al., 1986; Bradbury et al., 1993).

The infection usually affects nearly all chickens in a flock, but it is variable in severity and duration. It tends to be more severe and of longer duration in the cold months and affects younger birds more severely than mature birds, (Ley and Yoder, 1997). The most characteristic signs of the naturally occurring disease in adult flocks are tracheal rales, nasal discharge, and coughing (Ley and Yoder, 1997). In laying flocks, egg production declines but is usually maintained at a lower level (Mohammed et al., 1987). However, flocks may have serologic evidence of infection with no obvious clinical signs, especially if they encountered the infection at a younger age and have partially recovered (Ley, 2003).

Current measures to combat MG infection have included flock testing and eradication programs (Ahmad et al., 2008). Serologic procedures are useful for flock monitoring in MG control programmes and to aid in diagnosis when infection is suspected (Ley and Yoder, 1997). Several serologic tests like serum plate agglutination (SPA), haemagglutination inhibition (HI) and enzyme-linked immunosorbent assay (ELISA) are used as initial screening tests for flock monitoring and sero-diagnosis of MG infection (Ryan, 1973; Talkington et al., 1985; Avakian et al., 1988). Among these tests, SPA test is very simple, easy to do and cost-effective under field condition. In Bangladesh, limited data are available about the seroprevalence of MG infection in commercial layer birds by using SPA (Sikder et al., 2005; Hossain et al., 2007). This paper describes the seroprevalence of MG infection in non-vaccinated layer birds in five upazilas of Khulna district of Bangladesh. 


\section{MATERIALS AND METHODS}

\section{Study area and population}

A cross sectional study was conducted on 1,64,120 commercial layer birds of 96 farms in six upazilas (Sadar, Batiaghata, Dumuria, Dighulia, Rupsha and Fultala) of Khulna district during the period from August 2009 to July 2010 .

\section{Sample collection}

A total of 1268 blood samples without any anticoagulant were collected aseptically from wing vein of layer birds using sterile syringe and needle. Sera were separated and stored at $-20^{\circ} \mathrm{C}$ until used.

\section{Serum plate agglutination (SPA) test}

Standard MG (Nobilis ${ }^{\circledR}$ MG, Intervet International) was used for serum plate agglutination (SPA) test for the detection MG antibodies in the sera samples. The SPA test was conducted according to the manufacturer's instruction. Briefly, $0.02 \mathrm{ml}$ of antigen and $0.02 \mathrm{ml}$ of chicken serum were placed side by side with micropipettes on a glass plate. After that antigen and serum sample were mixed thoroughly by stirring with a small tooth pick. Then the glass plate was illuminated from below so as to facilitate observing the reaction, avoiding excessive heat from the light source. Positive reaction was characterized by the formation of definite clumps within 2 minutes after mixing the test serum with antigen. The clumps usually started appearing and became concentrated at the periphery of the mixture. Negative reaction was judged by the absence of agglutination reaction. Care was taken so that no natural granulation of the antigen could be taken as a positive reaction.

\section{Statistical analysis}

Chi-square test was done to find out the relationship between seroprevalence of MG infection and independent variables (age of birds, seasons and different areas of study) by using SPSS 11.5.

\section{RESULTS AND DISCUSSION}

The overall prevalence of MG infection was $67.4 \%$ (Table 1). The finding is in close agreement with the earlier report of Chrysostome et al. (1995) who reported 62\% seroprevalence of MG infection in layer chickens. However, the overall prevalence was somewhat higher than those of inland reports by Sarkar et al. (2005), Sikder et al. (2005) and Hossain et al. (2007) who reported 58.9\%, 46.88\% and 55.13\% seroprevalence, respectively. This variation might be due to variations in nature of poultry farming, operational practices and other biosecurity measures (Pradhan, 2002; Dulali, 2003).

Table 1. Age-wise seroprevalence of Mycoplasma gallisepticum (MG) infection in layer birds in six upazilas under Khulna district

\begin{tabular}{|c|c|c|c|c|c|c|c|c|c|}
\hline \multirow[t]{4}{*}{ Upazilas } & \multicolumn{9}{|c|}{ Seroprevalence of MG infection } \\
\hline & \multicolumn{2}{|c|}{ Pullet (8-20 wks) } & \multicolumn{2}{|c|}{ Layer (21-56 wks) } & \multicolumn{2}{|c|}{ Layer (>56 wks) } & \multicolumn{2}{|c|}{ Overall } & \multirow{3}{*}{$\begin{array}{c}\chi^{2} \\
\text { value }\end{array}$} \\
\hline & \multirow{2}{*}{$\begin{array}{l}\text { No. } \\
\text { tested }\end{array}$} & \multirow{2}{*}{$\frac{\text { Prevalence }}{\text { No. }(\%)}$} & \multirow{2}{*}{$\begin{array}{l}\text { No. } \\
\text { tested }\end{array}$} & \multirow{2}{*}{$\frac{\text { Prevalence }}{\text { No. }(\%)}$} & \multirow{2}{*}{$\begin{array}{l}\text { No. } \\
\text { tested }\end{array}$} & \multirow{2}{*}{$\frac{\text { Prevalence }}{\text { No. }(\%)}$} & \multirow{2}{*}{$\begin{array}{l}\text { No. } \\
\text { tested }\end{array}$} & \multirow{2}{*}{$\frac{\text { Prevalence }}{\text { No. }(\%)}$} & \\
\hline & & & & & & & & & \\
\hline Sadar & 137 & $102(74.5)$ & 333 & $233(70.0)$ & 163 & $90(55.2)$ & 633 & $425(67.1)$ & \multirow{6}{*}{66.18} \\
\hline Batiaghata & 27 & $15(55.6)$ & 269 & $233(86.6)$ & 43 & $27(62.8)$ & 339 & $275(81.1)$ & \\
\hline Dumuria & 6 & $4(66.7)$ & 43 & $18(41.9)$ & 0 & $0(0)$ & 49 & $22(44.9)$ & \\
\hline Dighulia & 29 & $12(41.4)$ & 45 & $20(44.4)$ & 44 & $38(86.4)$ & 118 & $70(59.3)$ & \\
\hline Rupsha & 3 & $2(66.7)$ & 66 & $35(53.0)$ & 15 & $5(33.3)$ & 84 & $42(50)$ & \\
\hline Fultala & 0 & $0(0)$ & 15 & $10(66.7)$ & 30 & $10(33.3)$ & 45 & $20(44.4)$ & \\
\hline Total & 202 & $135(66.8)$ & 771 & $549(71.2)$ & 295 & $170(57.6)$ & 1268 & 854 (67.4) & \\
\hline$\chi^{2}$ value & \multicolumn{8}{|c|}{17.92} & \\
\hline
\end{tabular}


Age-wise analysis revealed that there was significant relationship $(\mathrm{p}<0.001)$ between MG infection and age of birds. The highest prevalence of MG infection was $71.2 \%$ in $21-56$ weeks age group followed by $66.8 \%$ in $8-20$ weeks age group. The lowest prevalence was $57.6 \%$ in age group of above 56 weeks (Table 1). Similar observation was made by Hossain et al. (2010) who recorded the highest prevalence (71.6\%) at 16-23 weeks of age and lowest $(50.4 \%)$ at $\geq 64$ weeks of age. Some other earlier reports also support the present finding where lowest prevalence was recorded in birds of $\geq 55$ weeks of age and highest at 18-20 weeks of age (Sarkar et al., 2005; Sikder et al., 2005). In the present study, a large number of samples were collected from birds of 21-56 weeks of age during winter season, which may explain the higher prevalence in this age group than that of 8-20 weeks age group. According to areas, higher prevalence was recorded in Batiaghata, Dighulia and Sadar upazilas compared to those of Dumuria, Rupsha and Fultala upazilas (Table 1). There was significant $(\mathrm{p}<0.001)$ variation in the seroprevalence in terms of areas of study (upazilas). Batiaghata and Dighulia upazilas are very adjacent to Sadar upazila and farm density is very high in these two upazilas including Sadar upazila which may be one of the factors associated with higher prevalence.

Significant $(p<0.001)$ effect of seasons in the seroprevalence of MG infection in layer birds was observed in the present study. The prevalence of MG infection was the highest (75.6\%) in winter season followed by summer $(66.3 \%)$ and rainy $(60.8 \%)$ seasons (Table 2). This finding is in accordance with the reports of earlier observers who reported higher prevalence in winter season in comparison to summer and rainy seasons (Sarkar et al., 2005; Hossain et al., 2010).

Table 2. Season-wise seroprevalence of Mycoplasma gallisepticum infection in layer birds in six upazilas under Khulna district

\begin{tabular}{llllll}
\hline Seasons & Population & $\begin{array}{l}\text { No. of } \\
\text { samples tested }\end{array}$ & $\begin{array}{l}\text { No. of samples } \\
\text { positive }\end{array}$ & Prevalence (\%) & $\chi^{2}$ value \\
\hline Summer & 54650 & 383 & 254 & 66.31 & 22.19 \\
Rainy & 55570 & 467 & 284 & 60.81 & 75.59 \\
Winter & 53900 & 418 & 316 & 67.35 & \\
\hline Total & 164120 & 1268 & 854 & \\
\hline
\end{tabular}

Table 3. Effect of flock size on the seroprevalence of Mycoplasma gallisepticum infection in layer birds

\begin{tabular}{llllll}
\hline Flock size & No. of flocks & $\begin{array}{l}\text { No. of samples } \\
\text { tested }\end{array}$ & $\begin{array}{l}\text { No. of samples } \\
\text { positive }\end{array}$ & Prevalence (\%) & $\chi^{2}$ value \\
\hline $500-1500$ & 56 & 381 & 241 & 63.25 \\
$1501-2500$ & 27 & 459 & 312 & 70.15 & 50.00 \\
$2501-3500$ & 6 & 160 & 80 & 100.00 & 68.76 \\
$3501-4500$ & 1 & 24 & 24 & 69.57 & 90.70 \\
$4501-5500$ & 3 & 115 & 80 & 67.35 \\
$5500-$ above & 3 & 129 & 117 & \\
\hline Total & 96 & 1268 & 854 & \\
\hline
\end{tabular}

The seroprevalence of MG infection was higher in most of the large flocks and lower in small flocks with some exceptions (Table 3). Higher prevalence in large scale flocks might be due to the faulty in management and biosecurity measures (Chandiramani et al., 1996).

It is evident from the present study that above 50\% layer birds are infected with MG organism. Therefore, it may be suggested that the layer farms should be routinely checked to monitor MG infection and the reactor birds should be culled since MG organism has the potential to transmit vertically. 


\section{REFERENCES}

1. Ahmad A, Rabbani M, Yaqoob T, Ahmad A, Shabbir MZ and Akhtar F (2008). Status of IGG antibodies against Mycoplasma gallisepticum in non-vaccinated commercial poultry Breeder flocks. The Journal of Animal and Plant Sciences 18: 61-63.

2. Avakian AP, Kleven SH and Glisson JR (1988). Evaluation of the specificity and sensitivity of two commercial enzyme linked immunosorbent assay kits, the serum plate agglutination test and haemagglutination inhibition test for antibodies formed in response to Mycoplasma gallisepticum. Avian Diseases 32: 262-272.

3. Bradbury JM, Abul Wahab OMS, Yavari CA, Dupiellet JP and Bove JM (1993). Mycoplasma imitates SP. Nov. is related to Mycoplasma gallisepticum and found in birds. International Journal of Systemic Bacteriology 43: 721728.

4. Chandiramani NK, Van Roekeld H and Olesiuk OM (1966). Viability studies with Mycoplasma gallisepticum under different environment conditions. Poultry Science 45: 1029-1044.

5. Chrysostome CAAM, Bell JG, Demey F and Verhulst A (1995). Seroprevalences to three diseases in village chickens in Benin. Preventive Veterinary Medicine 22: 257-261.

6. Dulali RS (2003). Seroprevalence and pathology of mycoplasmosis in sonali chickens. MS Thesis, Department of Pathology, Faculty of Veterinary Science, Bangladesh Agricultural University, Mymensingh, Bangladesh.

7. Hossain KMM, Ali MY and Haque MI (2007). Seroprevalence of Mycoplasma gallisepticum infection in chicken in the greater Rajshahi district of Bangladesh. Bangladesh Journal of Veterinary Medicine 5: 09-14.

8. Hossain KMM, Hossain MT and Yamato I (2010). Seroprevalence of Salmonella and Mycoplasma gallisepticum infection in Chickens in Rajshahi and surrounding District of Bangladesh. International Journal of Biology 2: 7480.

9. Jordan FTW and Amin MM (1980). A survey of Mycoplasma infections in domestic poultry. Research in Veterinary Science 28: 96-100.

10. Ley DH (2003). Mycoplasma gallisepticum infection. In: Diseases of Poultry. $11^{\text {th }}$ edn., Saif YM, Barnes HJ, Fadly AM, Glisson JR, Mc Dougald LR and Swayne DE (eds.). Iowa State University Press, Ames, Iowa. pp. 722744.

11. Ley DH and Yoder HW, Jr (1997). Mycoplasma gallisepticum infection. In: Diseases of Poultry. $10^{\text {th }}$ edn., Calnek BW, Barnes HJ, Beard CW, Mc Dougald LR and Saif YM (eds.), Iowa State University Press, Ames, Iowa. pp. 194-207.

12. Mohammed HO, Carpenter TE and Yamamoto R (1987). Economic impact of Mycoplasma gallisepticum and M. synoviae in commercial layer flocks. Avian Diseases 31: 477-482.

13. Pradhan MAM (2002). Studies on Avian mycoplasmosis: Prevalence, Isolation, Characterization and Antigenic properties. PhD Thesis. Department of Microbiology and Hygiene, Faculty of Veterinary Science, Bangladesh Agricultural University, Mymensingh, Bangladesh.

14. Reece RL, Ireland L and Barr DA (1986). Infectious sinusitis associated with Mycoplasma gallisepticum in gamebirds. Australian Veterinary Journal 63: 167-168.

15. Ryan TB (1973). The use of microtiter hemagglutination-inhibition in Mycoplasma gallisepticum testing program. Proceedings of United States Animal Health Association 77: 593-595.

16. Sarkar SK, Rahman MB, Rahman M, Amin KMR, Khan MFR and Rahman MM (2005). Sero-prevalence of Mycoplasma gallisepticum infection in chickens in model breeder poultry farms of Bangladesh. International Journal of Poultry Science 4: 32-35.

17. Sikder AJ, Islam MA, Rahman MM and Rahman MB (2005). Seroprevalence of Salmonella and Mycoplasma gallisepticum infection in the six model breeder farms at Patuakhali district of Bangladesh. International Journal of Poultry Science 4: 905-910.

18. Talkington FD, Kleven SH and Brown J (1985). An enzyme-linked immunosorbent assay for the detection of antibodies to Mycoplasma gallisepticum in experimentally infected chickens. Avian Diseases 29: 53-70. 